\title{
FORUM
}

\section{Multitrophic Relationships, Conditional Mutualisms, and the Study of Interaction Biodiversity in Tropical Savannas}

\author{
Kleber Del-Claro \\ Instituto de Biologia,Universidade Federal de Uberlândia, C. postal 593, 38400-902, Uberlândia, MG, \\ delclaro@ufu.br
}

Neotropical Entomology 33(6):665-672 (2004)
Relações Multitróficas, Mutualismos Condicionais e o Estudo da Interação da Biodiversidade em Savanas Tropicais

\begin{abstract}
RESUMO - A biodiversidade como um foco em esforços de conservação tem recebido cada vez mais atenção desde a segunda metade do século passado. Até recentemente a visão da biodiversidade ao nível da paisagem (comunidades) tem prevalecido. Este ensaio se propõe a discutir a diversidade natural também através da riqueza extrema inerente às interações entre animais e plantas, incluindo não apenas relações tróficas, mas também aspectos de histórias de vida, biologia e comportamento das espécies relacionadas. Sistemas plantas-formigas-herbívoros na vegetação de Cerrado são aqui apontados como modelos apropriados para aumentar a compreensão sobre a "biodiversidade interativa".
\end{abstract}

PALAVRAS-CHAVE: Cerrado, formiga, herbívoro, nectário extrafloral, planta

\begin{abstract}
Biodiversity as a focus for conservation efforts has received increased attention since the second half of the last century. Until recently a more landscape-level view of biodiversity has prevailed. This essay proposes to discuss natural diversity in ways that embrace the extreme richness inherent in plant animal interactions, including not only trophic relationships, but also aspects of life history, biology, and behavior of related species. The ant-plant-herbivore systems in Cerrado vegetation are pointed out as good model for gaining a better understanding of "interaction biodiversity".
\end{abstract}

KEY WORDS: Ant, Cerrado, extrafloral nectary, herbivory, plant

Biodiversity as a focus for conservation efforts has received increased attention since the second half of the last century

(Wilson 1988, Pearson 1994). Searching for patterns in biodiversity, researchers have suggested various units of study including ecological communities (Hunter et al. 1988), cladistic classifications (Vane-Wright et al. 1991), hierarchical composite of different levels of organization (Noss 1990), and also groups of taxonomically related species (Holloway \& Jardine 1968). The study of biodiversity, therefore, has great complexity. On the other hand, because of public and political pressures, studies of biodiversity have often relied on subjective approaches to understanding and resolving urgent problems (Maguire 1991). Thus, programs for conservation of natural systems have been concerned primarily with the maintenance of species diversity and ecosystem function, and the preservation of genetic variation within populations (Thompson 1997, Oliveira \& Del-Claro in press). Until recently a more landscape-level view of biodiversity has prevailed.

In a more recent and realistic perspective, however, biodiversity should be viewed and evaluated also in ways that embrace the extreme richness inherent in plant animal interactions, including not only trophic relationships (Price 2002), but also aspects of life histories, biology and behavior of related species (Oliveira \& Del-Claro in press). Fig.1A, for example, shows a Thomisidae spider preying on a honeybee in an inflorescence. An astute observer will perceive that while the spider is feeding on a possible plant pollinator, three flies, in the bee head, are also sucking fluid secretions from prey's body, contesting against the hunter. Ones could ask several questions: if the spider is harming plant pollination through bee predation, are these flies an additional problem to the plant? Or, by competing with the spider, can the flies indirectly benefit the plant? Could the parasitic action of flies be discouraging the spider to remain in this plant? How many species are involved in this system?

Here, this issue is examined through the study of the intricate nature of multitrophic interactions mediating the outcome of insect-plants relationships. The ant-plant-herbivore systems will be pointed out as good models for gaining a 


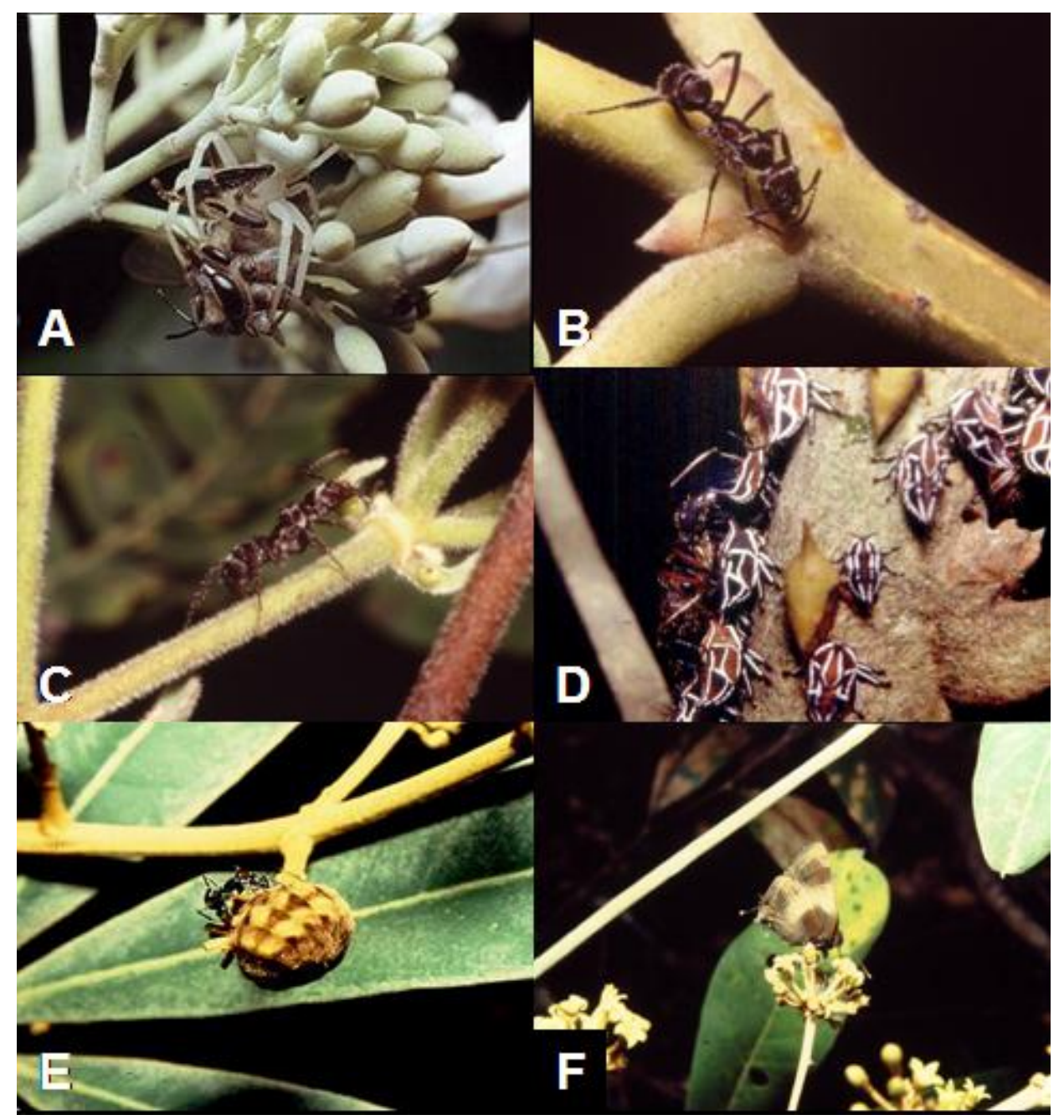

Figure 1. A) Spider, Thomisidae, preying a honeybee. Note the flies sucking the bee head; B) Ectatomma brunneum F. Smith visiting an extrafloral nectary of Qualea multiflora Mart.; C) E. brunneum visiting an extrafloral nectary of Peixotoa tomentosa A. Juss.; D) Camponotus rufipes Fabr. collecting honeydew from nymphs of Guayaquila xiphias Fabr.; E) $C$. crassus Mayr tending larvae of Panthiades polibethes Cramer.; F) An adult butterfly of $P$. polibethes in a flower of the host plant Didymopanax vinosum March.

better understanding of "interaction biodiversity" (Thompson 1997), an integral part of strategies to maintain viable communities (Oliveira \& Del-Claro in press). The examples will focus on the Cerrado vegetation (the Brazilian tropical savanna), with the goal of stimulating research in one of the most endangered ecosystem in the southern hemisphere.

\section{Ant-Plant Interactions}

We cannot discuss terrestrial biodiversity without talking about ants, simply because in many habitats ants comprise a major part of the arthropod fauna found on vegetation. Recent studies have shown that the abundance and diversity of antplant associations is particularly remarkable in the tropical region (Oliveira \& Oliveira-Filho 1991, Rico-Gray 1993, Del-Claro et al. 1996, Oliveira \& Pie 1998). Many ant species use plant surfaces as a foraging substrate to search for both live and dead animal prey, as well as for different types of plant-derived food products (Carroll \& Janzen 1973). Ant activity on foliage can be promoted by the occurrence of predictable and immediately renewable food sources, such as extrafloral nectar, honeydew from phloemfeeding hemipterans, and secretions from lepidopteran larvae. Indeed, plant- and insect-derived liquid foods appear to provide a large amount of the energy supply to foliage-dwelling ants (Tobin 1994, Davidson et al. 2003). Thus, ant activity on vegetation has produced a wide variety of ant-plant-herbivore interactions, ranging from facultative to obligate associations (Beattie 1985, Davidson \& McKey 1993, Bronstein 1998). In most introductory biology textbooks, this type of relationships between organisms of two species in which both species benefit each other have been defined as mutualism (e.g., Boucher et al. 1982, Thompson 1994). 


\section{Variation in the Outcomes of Mutualism}

Despite its abundance, the influence of other species and other trophic levels on mutualisms has received little attention, particularly in contrast to other types of interactions (Bronstein \& Barbosa 2002). In fact, the full range of multitrophic effects on mutualism demands further studies mainly considering evolutionary consequences.

Extrafloral nectary-bearing plants are good models to study multitrophic effects on mutualism and biodiversity. In these types of plants, visiting ants that exhibit aggressive behaviour towards herbivores can positively affect plant fitness by decreasing herbivore damage to vegetative and reproductive plant parts (Koptur 1992, Oliveira \& Pie 1998). There are many definitions of extrafloral nectaries (EFNs), but those that define EFNs as nectaries that are not involved in pollination (e.g., Fiala \& Maschwitz 1991) are the most simple and correct. EFNs have been recorded from more than 93 angiosperm families (Koptur 1992) in at least 2200 species (Keeler 1989). Although plants bearing EFNs may account for up to $31 \%$ of the woody individuals and $25 \%$ of the woody species in the Cerrado community of Brazil (Oliveira \& Oliveira-Filho 1991, Oliveira \& Pie 1998), the effects of visiting ants on herbivore damage to vegetative and reproductive plant parts was shown by the first time in South America only in 1996.

Studying Qualea multiflora Mart. (Vochysiaceae) its herbivores and associated ants (Fig. 1B), Del-Claro et al. (1996) not only showed that ants could reduce herbivory damage to leaves (Oliveira et al. 1987, Costa et al. 1992), but also that ant impact on bud and flowers herbivory could enhance seed production significantly. Seven ant species protected leaves of $Q$. multiflora against a great diversity of herbivores, including grasshoppers, beetles, and leaf sucking hemipterans. No species of leaf herbivores were significantly abundant. Price et al. (1995) showed that in general Cerrado has a great diversity, but not a great abundance of insect herbivores. In $Q$. multiflora trees, however, the beetle Macrodactylus pumilio Burm. (Scarabaeidae: Melolontinae) was very abundant, eating entire buds and also the reproductive parts of flowers. By defeating and attacking the beetles, ant presence reduced mainly the time that these herbivores had to feed on plants, significantly benefiting the Vochysiaceae reproduction (Del-Claro et al. 1996). However, this was not always true in this mutualistic system. The experiment was repeated in the same Cerrado area two years later, analysing data for two years (Queiroz \& Del-Claro, unpublished). The results showed increase in the number of associated ant species ( 7 to 15 ) and reduction in leaf herbivory by chewing insects. However, the herbivory decrease depended on ant presence, and it occurred only during the months in which plants were producing new leaves (after winter). EFNs are active and true attracting ants to fed on them, only in expanding leaves. Ants can perceive variation in food source and change its choices between seasons or areas (Rico-Gray 1993). Additionally, insect fauna can change between seasons and years depending on variations in temperature and humidity (Marquis \& Braker 1984, Del-Claro \& Oliveira 2000). In another study the number of beetles $M$. pumilio in buds and flowers of Q. multiflora was very low and no difference was observed between groups in fruit production per buds developed (Queiroz \& Del-Claro, unpublished). Combined results of experiments in $Q$. multiflora plants in Cerrado vegetation (Del-Claro et al. 1996, Queiroz \& Del-Claro, unpublished), showed that the interaction can change depending on a series of conditions, including seasonal variations acting on herbivores diversity and abundance, producing also variations in the outcomes of the interaction. The variation in diversity of associated species through time is an important source of variability in the relationships between ants, plants and herbivores, however; spatial variability may be just as important in generating conditionality in mutualism as temporal variation.

Peixotoa tomentosa A.Juss. is a common Malpighiaceae in the Cerrado vegetation of Minas Gerais State, bearing EFNs in the basis of its leaves (Fig. 1C). Studying tri-trophic interactions in this plant species, Del-Claro (1998) showed that ants can benefit the plant against leaf and floral herbivory. Leaf herbivory in $P$. tomentosa is produced mainly by chewing insects like beetles, grasshoppers, and leaf-cutting ants. Floral damage is a result of the action of some beetle species, but mainly due to a Thysanoptera, Heterothripes peixotoa DelClaro, Marullo \& Mound, that attacks the reproductive structures (Del-Claro et al. 1997). The study was conduced for three years (Del-Claro 1998), and results showed that ant benefit to plants can vary as temporally as spatially. Depending probably on climatic variation, the abundance of thysanopterans varies between years. In years of low abundance of $H$. peixotoa, presence or absence of ants had no differential effect on plant productivity. However, when the herbivores were common in the field the presence of ants produced a significant increase in seed and fruit production. The benefit can depend not only of time and season, but also from site and ant species. Del-Claro (1998) showed that the thysanopterans are efficiently removed from plants only by small ant species that are able to enter inside floral structures to capture them (Fig. 2). Thus, the variation in the characteristics of the environment can result in distinct ant fauna visiting plants, thereby producing different results. It is dramatic in the case of P. tomentosa because in one of the years of study the selected plants were in an area full of leafcutting ant nests (Atta laevigatta Smith). The associated ants were ineffective against Attini ants that destroyed the major part of leaves, buds, and flowers in control plants.

\section{Conditional Mutualisms}

Ecological forces that cause a mutualism to vary in space and in time is termed "conditional mutualism" (Herre et al. 1999). To understand this phenomenon it is particularly important to know multitrophic interactions and how they can affect biodiversity. In this sense, relationships involving ants tending insects, such as treehoppers and aphids, butterfly larvae and plants are important models for studying conditional mutualisms (Bronstein \& Barbosa 2002, Billick \& Tonkel 2003). New insights in the study of the evolutionary ecology of ant-Hemiptera (Auchenorryncha and Sternorryncha) and ant-Lepidoptera systems, including 

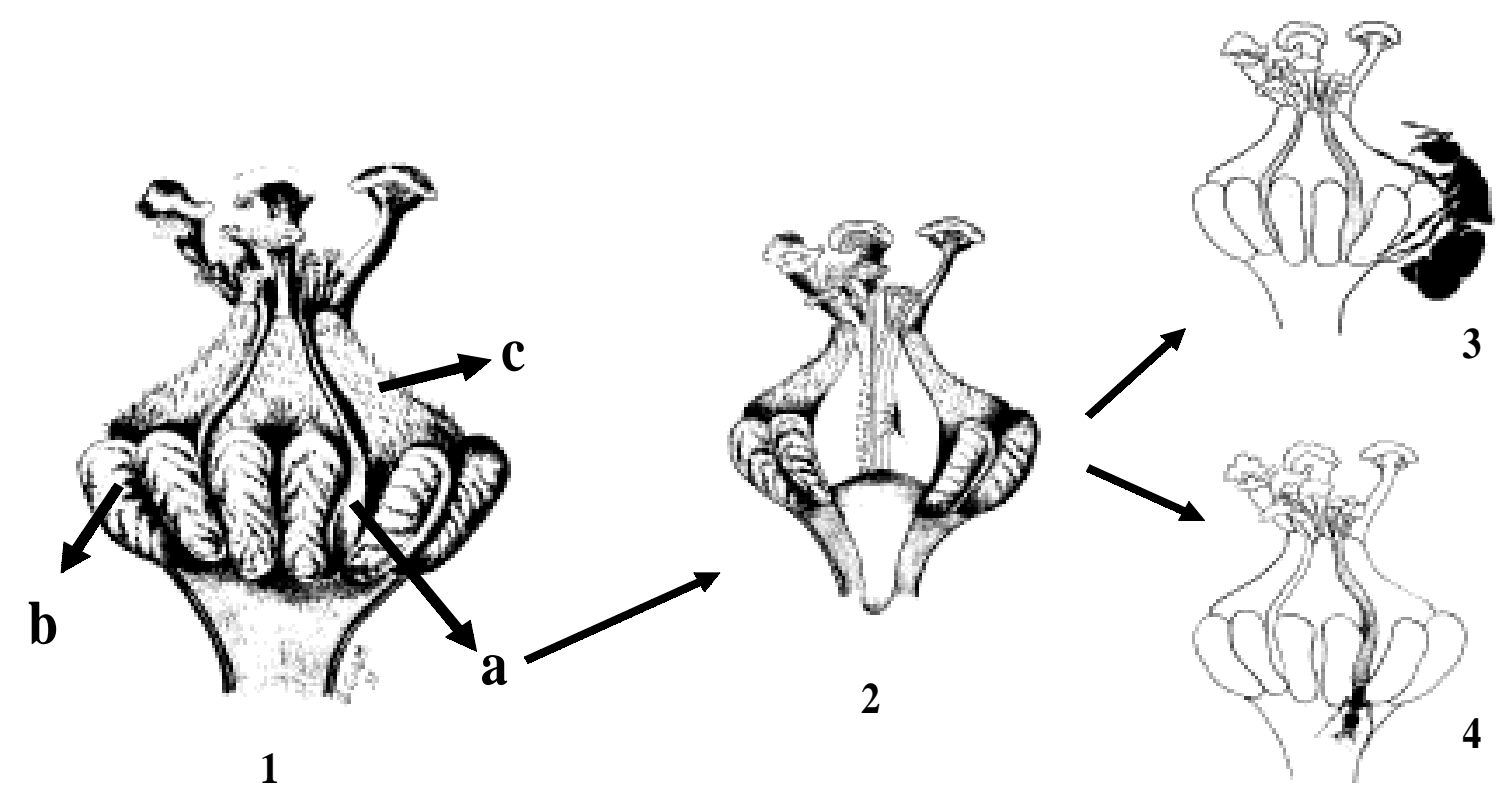

Figure 2. 1) A flower of Peixotoa tomentosa A. Juss., without its petals to show the opening between the sepals used by thrips and small ants to entry inside the flower (a), oil glands (b) and sepals (c); 2) Heterothripes peixotoa Del-Claro, Marullo \& Mound sucking the reproductive structures of flower; 3) Figure showing the large ants like Ponerinae and several Formicinae that can not get inside the flower due to its size; 4) Figure showing that small ants like several Myrmicinae and Pseudomyrmicinae are able to get inside the flower and prey on thrips.

reviews of the most important works, can be found in recent literature (e.g., Morales 2000, Billick et al. 2001, Delabie 2001, Beattie \& Hughes 2002, Brosntein \& Barbosa 2002, Oliveira et al. 2002, Pierce et al. 2002, Billick \& Tonkel 2003, Oliveira \& Del-Claro in press).

The remainder of this essay will focus on the variation and conditionality in the outcomes of an ant-membracid relationship, with emphasis on the impacts of tending ants on the associated arthropod fauna. The study was conducted in a natural reserve nearby of Mogi-Guaçu (SE Brazil; 22 ${ }^{\circ} 18^{\prime} \mathrm{S}$, $\left.47^{\circ} 10^{\prime} \mathrm{W}\right)$. The vegetation consists of a dense scrub of shrubs and trees, known as Cerrado sensu stricto (Oliveira-Filho \& Ratter 2002). Aggregations of Guayaquila xiphias Fabr. (Membracidae) commonly infest shrubs of Didymopanax vinosum March. (Araliaceae), where the theehoppers are tended by a diverse assemblage of honeydew-gathering ants (Fig.1D). Treehoppers occur on D. vinosum throughout the year, and levels of infestation on a plant range from one female with her egg mass to around 200 individuals in a single aggregation (mean $\pm \mathrm{SD}=18.8 \pm 23.6 ; \mathrm{n}=222$ ). Summarizing the main results (Del-Claro \& Oliveira 1993, 1996, 1999, 2000), we observed that 21 different ant species are associated to the membracid and that daily turnover of ant species at a given treehopper aggregation frequently occurs (Del-Claro $\&$ Oliveira 1999). The number of individuals and species of ants collecting honeydew (membracid exsudate - its faeces rich in water, sugar, amino acids and other compounds), vary not only through the day, but also through the months of the year. So, there is temporal variation in this association. Locally, depending on ant nest presence and distance to the host plant, spatial variation is observed in this system as well
(Dansa \& Rocha 1992). G. xiphias are attacked by three main types of natural enemies on shrubs of $D$. vinosum: 1 ) A total of 15 species of salticid spiders may prey on nymphs and adults; 2) predatory larvae of Ocyptamus arx (Fluke) (Diptera: Syrphidae) suck empty the entire body contents of the treehoppers, and occasionally feed on egg masses after prey on all nymph or adult treehopper present on the plant; and 3) treehopper egg masses are parasitized by Gonatocerus wasps (Myrmaridae).

A series of controlled ant-exclusion experiments performed in the Cerrado enabled to assess the nature of the benefits afforded by tending ants to G. xiphias, and identify the variable outcomes of the interaction (Del-Claro \& Oliveira 2000). These results showed that ant benefits included mainly protection against natural enemies, and reduction in egg parasitism, that resulted in better reproduction and higher survivorship. However, results also showed that the benefits could vary strongly between years depending on climate variations that can produces variation in the abundance of natural enemies. These benefits were also strongly influenced by the behavior of associated ant partner. In hotter years, with higher abundance of natural enemies in the field, only one ant species was able to offer protection against natural enemies to the threehoppers, the Formicinae Camponotus rufipes Fabr. (Oliveira et al.2002). Clearly, the functioning of these interactions is conditional and multitrophic, but how it can affect the host plant fitness and local biodiversity?

Carroll \& Janzen (1973) first suggested that honeydewproducing hemipterans could function as insect analogs of extrafloral nectaries due to tending ants' deterrence of other herbivores associated with the plant. In theory, in order for 
the ant-hemipteran association to positively affect plant fitness, protection from herbivory should outweigh the losses incurred by hemipteran feeding. The ant-tended partner should also not be the primary herbivore, and the ants should effectively deter non-hemipteran herbivores (Messina 1981; see also Horvitz \& Schemske 1984 on ant-tended lepidopteran larvae). Searching to close question in the case of G. xiphias, Oliveira \& Del-Claro (in press) investigated the outcomes of the relationship to the host-plant point of view.

Shrubs of the host plant, $D$. vinosum, are infested by four principal non-hemipteran insect herbivores: Liothrips didymopanicis Del-Claro \& Mound (Thysanoptera: Phlaeothripidae): thrips consume the apical leaf primordial and young leaves; Caralauca olive Jesmar (Coleoptera: Chrysomelidae): adults mate on the host plant and feed mainly on mature adult leaves. Leaf-miners (Lepidoptera, undetermined family): the activity of larvae leaves is easily detectable by the presence of tunnels within the leaf blade; and Panthiades polibethes Cramer (Lepidoptera: Lycaenidae). The cryptic caterpillars rest and feed on floral buds and are tended from the earliest instars by at least seven ant species that feed on larval secretions (Fig. 1E).

Through a series of experimental manipulations in the field Oliveira \& Del-Claro (in press) demonstrated that the presence of ant-Guayaquila infestations can strongly benefit the host plant against its main natural enemies. Shortening, in the absence of the infestation, thysanopteran can destroy the apical meristem or cause serious damage to young leaves, witch reduces plant fitness. Plants with the apical meristem destroyed can die or not produce inflorescences. Herbivore by chewing and mining insects was significantly lower in the presence of ant-membracid interactions. The benefits produced by ants can be direct through herbivore predation or indirect by displacing chewing and other insects from the host plant, or reducing its time feeding on leaves, meristems, buds, and flowers. However, the presence of ants on plants can attract an ant-mutualist herbivore, the butterfly $P$. polibethes (Fig. 1F). Plants with ant-Guayaquila infestations had its inflorescences significantly more attacked by butterfly larvae than plants without the infestations. Ants tend lycaenid larvae in the same manner they tend membracids and the butterfly feeds on buds of $D$. vinosum. Therefore, ask the question: how will be the outcomes of the ant- $D$. vinosum herbivores relationship now? Results (Oliveira \& Del-Claro in press) showed that the butterfly larva significantly reduces seed production in the host plant. Plants with ant-Guayaquila associations had greater fruit production than plants without the infestation and than plants without ant-membracids but with lycaenid larvae. However, plants with ants, membracids and lycaenids produced more fruits than plants without any infestation. Other herbivores feed on buds or flowers of this Araliaceae, and ants attracted by membracids and/or lycaenids are effective also to displace them.

\section{Conclusions}

The multitude of interactions in the ant-plant-herbivores systems shows us not only, how conditional they are (both temporary and spatially), but also some more specific points related to the ecology of ant-plant-arthropod interactions in tropics and specially on Cerrado. Species that comprise a community may be linked directly through interactions between resources and consumption (Polis \& Winemiller 1996). In systems involving three (or more) trophic levels, such as plants, herbivores, and predators, a trophic cascade describes the positive top-down effects of the third trophic level on the biomass, richness, or composition of the producer species (Hairston et al. 1960, Polis et al. 2000). Thus, the ant action reducing herbivores densities on plants can reduce chances of competitive exclusion between species having an additional and complementary effect to maintain the typical great diversity mainly of arthropods in Cerrado vegetation (see Price et al. 1995). Predators frequently have an impact on the density, spatial distribution, and diversity of herbivore assemblages, thereby altering the patterns and levels of herbivory in plant communities (Heads \& Lawton 1984, Schmitz \& Suttle 2001, Romero \& Vasconcellos-Neto 2004). Predator like ants can have the same impact on other predators and parasitoids of herbivores, also causing directly and indirectly effects on plant communities (Del-Claro \& Oliveira 2000).

The systems structured on $P$. tomentosa, D. vinosum and $Q$. multiflora plants are sympatric and several times placed side by side in Cerrado. Several ants, herbivores and other predators and parasitoids can be observed in two of these systems or same in the three and other systems in the same place and time. Thus, the studies reported here have shown in various ways that interspecific interactions can shape the organization of communities, and therefore act as links between species and ecosystems. Biodiversity should be viewed and evaluated also in ways that embrace the extreme richness inherent to plant-animal interactions, including the species' ecological roles, the kinds of interactions and their outcomes, trophic web structure, selection pressures, habitat heterogeneity, temporal and geographical variation (Price 2002). Nowadays, programs for conservation of biodiversity have been concerned primarily with maintenance the preservation of genetic variation within populations and species diversity and ecosystem functions. However, despite of inherent complexity of multitrophic interactions, priorities have been moved from the traditional landscape-level view of biodiversity, to a more complete view to maintain viable preserved communities, the study of "interaction biodiversity" (Thompson 1997).

\section{Acknowledgments}

I thank Dr. Antônio R. Panizzi for the opportunity to publish this essay. I also thank A.P. Korndörfer, E. Bruna, J.C. Santos, and H.M.T. Silingardi for valuable comments and for the English review. This research is supported by grants from $\mathrm{CNPq}(\mathrm{PQ})$ and Fapemig. This essay is dedicated to Dr. Paulo S.M.C. de Oliveira, for his contribution to the study of the Cerrado ecosystem.

\section{Literature Cited}

Beattie, A.J. 1985. The evolutionary ecology of ant-plant 
mutualisms. Cambridge University Press, Cambridge, $385 p$.

Beattie, A.J. \& L. Hughes. 2002. (eds.) Ant-plant interactions, p.211-235. In C.M. Herrera \& O. Pellmyr (eds.), Plant-animal interactions: An evolutionary approach. Oxford, Blackwell Science, 487p.

Billick, I. \& K. Tonkel. 2003. The relative importance of spatial vs. temporal variability in generating a conditional mutualism. Ecology 84: 289-295.

Billick, I., M. Weidmann \& J. Reithel. 2001. The importance of ant-tending to maternal care in the membracid species, Publilia modesta. Beh. Ecol. Sociobiol. 51: 41-46.

Boucher D.H., S. James \& K.H. Keeler. 1982. The ecology of mutualism. Annu. Rev. Ecol. Syst. 13: 315-347.

Bronstein, J.L. 1998. The contribution of ant-plant protection studies to our understanding of mutualism. Biotropica 30: $150-161$

Bronstein, J.L. \& P. Barbosa. 2002. Multitrophic/ multispecies mutualistic interactions: The role of nonmutualists in shaping and mediating mutualisms, p.44-66. In T. Tscharntke \& B.A. Hawkins (eds.), Multitrophic level interactions. Cambridge, Cambridge University Press, 587p.

Carroll, C.R. \& D.H. Janzen. 1973. Ecology of foraging by ants. Annu. Rev. Ecol. Syst. 4: 231-257.

Costa, F.M.C.B., A.T. Oliveira-Filho \& P.S. Oliveira. 1992. The role of extrafloral nectaries in Qualea grandiflora (Vochysiaceae) in limiting herbivory: an experiment of ant protection in cerrado vegetation. Ecol. Entomol. 17:363-365.

Dansa, C.V.A. \& C.F.D. Rocha. 1992. An ant-membracidplant interaction in a cerrado area of Brazil. J. Trop. Ecol. 8:339-348.

Davidson, D.W. \& D. McKey. 1993. The evolutionary ecology of symbiotic ant-plant relationships. J. Hymen. Res. 2: 13-83.

Davidson, D.W., S.C. Cook, R.R. Snelling \& T.H. Chua. 2003. Explaining the abundance of ants in lowland tropical rainforest canopies. Science 300: 969-972.

Delabie, J.H.C. 2001. Trophobiosis between Formicidae and Hemiptera (Sternorrhyncha and Auchenorrhyncha): an overview. Neotrop. Entomol. 30: 501-516.

Del-Claro, K. 1998. A importância do comportamento de formigas em interações: Formigas e tripes em Peixotoa tomentosa (Malpighiaceae), no cerrado. Rev. Etol. $1: 3-10$.
Del-Claro, K. \& P.S. Oliveira. 1993. Ant-homoptera interaction: Do alternative sugar sources distract tending ants? Oikos 68: 202-206.

Del-Claro, K. \& P.S. Oliveira. 1996. Honeydew flicking by treehoppers provide cues to potential tending ants. Anim. Behav. 51: 1071-1075.

Del-Claro, K. \& P.S. Oliveira. 1999. Ant-homoptera interactions in neotropical savanna: The honeydewproducing treehopper Guayaquila xiphias (Membracidae) and its associated ant fauna on Didymopanax vinosum (Araliaceae). Biotropica 31: 135-144.

Del-Claro, K. \& P.S. Oliveira. 2000. Conditional outcomes in a neotropical treehopper-ant association: temporal and species-specific effects. Oecologia 124: 156-165.

Del-Claro, K., R. Marullo \& L.A. Mound. 1997. A new species of Heterothripes (Thysanoptera) from Brazilian cerrados and its interactions with ants. J. Nat. Hist. 31: 1307-1312.

Del-Claro, K., V. Berto \& W. Réu. 1996. Herbivore deterrence by visiting ants increases fruit-set in an extrafloral nectary plant Qualea multiflora (Vochysiaceae) in cerrado vegetation. J. Trop. Ecol.12: 887-892.

Fiala, B. \& U. Maschwitz. 1991. Extrafloral nectaries in the genus Macaranga (Euphorbiaceae) in Malaysia; comparative studies of their possible significance as predispositions for myrmecophitism. Biol. J. Linnean Soc. 44:287-305.

Hairston, N.G., F.E. Smith \& L.B. Slobodkin. 1960. Community structure, population control, and competition. Am. Nat. 94: 421-425.

Heads, P.A. \& J.H. Lawton. 1984. Bracken, ants and extrafloral nectarines. II. The effect of ants on the insect herbivores of bracken. J. Anim. Ecol. 53: 1015-1031.

Herre, E.A., M. Knowlton, U.G. Mueller \& S.A. Rehner. 1999. The evolution of mutualism: exploring the paths between conflict and cooperation. Trends Ecol. Syst. 14:49-51.

Holloway, J.D. \& N. Jardine. 1968. Two approaches to zoogeography: a study based on the distribution of butterflies, birds and bats in the Indo-Australian area. Proc. Linn. Soc. Lond. 179:153-188.

Horvitz C.C. \& D.W. Schemske 1984. Effects of ants and ant-tended herbivore on seed production of a neotropical herb. Ecology 65: 1369-1378.

Hunter Jr., M.L., G.L. Jacobson Jr. \& T. Webb III. 1988. Paleoecology and the coarse-filter approach to 
maintaining biological diversity. Conserv. Biol. 2: 375-385.

Keeler, K.H. 1989. Ant-plant interactions, p.207-240. In W.G. Abrahamson (ed.), Plant-animal interactions. New York, McGraw Hill, 481p.

Koptur, S. 1992. Extrafloral nectary-mediated interactions between insects and plants, p.81-129. In E. Bernays (ed.) Insect-plant interactions. v. 4. Boca Raton, CRC Press, $423 p$.

Maguire, L.A. 1991. Risk analysis for conservation biologists. Conserv. Biol. 50: 239-261.

Marquis, R.J. \& H.E. Braker. 1994. Plant-herbivore interactions: diversity, specificity, and impact, p 261281. In L.A. McDade, K.S. Bawa, H.A. Hespenheide \& G.S. Hartshorn (eds.), La selva: Ecology and natural history of a neotropical rain forest. Chicago, Chicago Press, 486p.

Messina, F.J. 1981. Plant protection as a consequence of ant-membracid mutualism: Interactions on goldenrod (Solidago sp.). Ecology 62: 1433-1440.

Morales, M.A. 2000. Mechanisms and density dependence of benefit in an ant-membracid mutualism. Ecology 81: 482-489.

Noss, R.F. 1990. Indicators for monitoring biodiversity: A hierarquical approach. Conserv. Biol. 4: 355-364.

Oliveira, P.S., A.F. Silva \& A.B. Martins. 1987. Ant foraging on extrafloral nectaries of Qualea grandiflora (Vochysiaceae) in cerrado vegetation: Ants as potential antiherbivore agents. Oecologia 74: 228-230.

Oliveira, P.S. \& A.T. Oliveira-Filho. 1991. Distribution of extrafloral nectaries in the woody flora of tropical communities in Western Brazil, p.163-175. In P.W. Price, T.M. Lewinsohn, G.W. Fernandes \& W.W. Benson (eds.), Plant-animal interactions: Evolutionary ecology in tropical and temperate regions. New York, John Wiley \& Sons, 639p.

Oliveira, P.S., A.V.L. Freitas \& K. Del-Claro. 2002. Ant foraging on plant foliage: Contrasting effects on the behavioral ecology of insect herbivores, p.287-305. In P.S. Oliveira \& R.J Marquis (eds.), The cerrados of Brazil: Ecology and natural history of a neotropical savanna. New York, Columbia University Press, 398p.

Oliveira, P.S. \& K. Del-Claro. Multitrophic interactions in a neotropical savanna: Ant-hemipteran systems, associated insect herbivores, and a host plant. In. D.F.R.P. Burslem, M.A. Pinard \& S.E. Hartley (eds). Biotic interactions in the tropics. Cambridge University Press,
Cambridge, UK. (in press).

Oliveira, P.S. \& M.R. Pie. 1998. Interaction between ants and plants bearing extrafloral nectaries in cerrado vegetation. An. Soc. Entomol. Bras. 27: 161-176.

Oliveira-Filho, A.T. \& J.A. Ratter. 2002. Vegetation physiognomies and woody flora of the cerrado biome, p.91-120. In P.S. Oliveira \& R.J Marquis (eds.), The Cerrados of Brazil: Ecology and natural history of a neotropical savanna. Columbia University Press, New York, 398p.

Pearson, D.L. 1994. Selecting indicator taxa for the quantitative assessment of biodiversity. Phil. Trans. R. Soc. Lond. B. 345: 75-79.

Pierce, N.E., M.F. Braby, A. Heath, D.J. Lohman, J. Mathew, D.B. Rand, M.A. Travassos. 2002. The ecology and evolution of ant association in the Lycaenidae (Lepidoptera). Annu. Rev. Ecol. Syst. 47: 733-771.

Price, P.W. 2002. Species interactions and the evolution of biodiversity, p. 3-25. In C.M. Herrera \& O. Pellmyr (eds.), Plant-animal interactions: An evolutionary approach. Oxford, Blackwell Science, 425p.

Price, P.W., I.R. Diniz, H.C. Morais \& E.S.A. Marques. 1995. The abundance of insect herbivore species in the tropics: High local richness of rare species. Biotropica 27: 468-478.

Polis, G.A., A.L. W. Sears, G.R. Huxel, D.R. Strong \& J. Maron. 2000. When is a trophic cascade a trophic cascade? Trends Ecol. Evol. 15: 473-475.

Polis, G.A. \& O. Winemiller. 1996. (eds.). Food webs. integration of patterns and dynamics. New York, Chapman \& Hall, 535p.

Rico-Gray, V. 1993. Use of plant-derived food resources by ants in the dry tropical lowlands of coastal Veracruz, Mexico. Biotropica 25: 301-315.

Romero, G.Q. \& J. Vasconcelos-Neto. 2004. Benefical effects of flower-dwelling predators on their host plant. Ecology 85: 446-457.

Schimtz, O. \& K.B. Suttle. 2001. Effects of top predator species on direct and indirect interactions in a food web. Ecology 82: 2072-2081.

Tobin, J.E. 1994. Ants as primary consumers: Diet and abundance in the Formicidae, p.279-308. In J.H. Hunt \& C.A. Nalepa (eds.), Nourishment and evolution in insect societies. Westview Press, Oxford, 412p.

Thompson, J.N. 1994. The coevolutionary process. The Univ. of Chicago Press, Chicago, 76p. 
Thompson, J.N. 1997. Conserving interaction biodiversity, p. 285-293. In S.T.A. Pickett, R.S. Ostfeld, M. Shachak, \& G.E. Likens (eds.), The ecological basis of conservation: Heterogeneity, ecosystems, and biodiversity. Chapman \& Hall, New York, 437p.
What to protect? - Systematics and the agony of choice. Biol. Conserv. 55: 235-254.

Wilson, E.O. 1988. (ed.). Biodiversity. Washington, D.C. National Academy Press, 538p.

Vane-Wright, R.I., C.J. Humphries \& P.H. Williams. 1991. Received 29/09/04. 